https://helda.helsinki.fi

\title{
Women Managers, Careers and Gendered Ageism
}

\section{Jyrkinen, Marjut Hannele}

2014

Jyrkinen, M H 2014 , ' Women Managers, Careers and Gendered Ageism ' , Scandinavian

Journal of Management, vol. 30 , no. 2 , pp. 175 . https://doi.org/10.1016/j.scaman.2013.07.002

http://hdl.handle.net/10138/159757

https://doi.org/10.1016/j.scaman.2013.07.002

acceptedVersion

Downloaded from Helda, University of Helsinki institutional repository.

This is an electronic reprint of the original article.

This reprint may differ from the original in pagination and typographic detail.

Please cite the original version. 


\title{
Women Managers, Careers and Gendered Ageism
}

\author{
It is good that in addition to looking beautiful you also have something in your head. \\ Comment by CEO to a young woman manager in recruitment interview
}

\section{Introduction}

This paper explores the intersectionality of gender and age in the careers of women managers through the use of data from semi-structured interviews with senior women managers in private and third sector organisations. Age, ageing and ageism have become increasingly topical given the demographic trend towards ageing working populations in many western(ised) countries. Attitudes and prejudices about policies and practices concerning ageing and older workers, and concerns about income in later life, are pertinent issues for both employing organisations and for workers (Wilkinson \& Ferraro, 2002). Age is also highly relevant in workforce recruitment, selection and retention, in performance and performance evaluation, as well as in training and career development (Perry \& Parlamis, 2006).

While there is an increasing amount of research and policy interest in age and ageing, less focus has been put on the intersection of gender and age. Earlier research indicates that women and men experience age, ageing and ageism in different ways in organisations and management (Itzin \& Phillipson, 1995; Ilmarinen, 2005). Duncan and Loretto's (2004) survey study of the financial sector in the UK suggests that women experience more age discrimination than do men. Another UK study (Granleese \& Sayer, 2005) found that women in higher education are discriminated against in ways that differ from those that men identify: women experience a triple jeopardy of discrimination because of age, gender and 'lookism'.

In this paper I draw upon empirical data to explore gender, age and gendered ageism. Ageism refers to negative stereotyping and discrimination based on age, mainly, but not always, older age. Ageism covers both implicit and explicit thoughts, feelings and behaviours that are based on prejudices and myths concerning people of older age ${ }^{i}$. Gendered ageism refers to discriminatory actions, whether intentional or non-intentional, that are based on the intersection of gender and age. Gendered ageism is not limited to relations between men and women, but manifests also between women as well as between men.

The material derived from the interviews with women senior managers illuminates the intersectionality of gender and age (e.g. Crenshaw, 1991; Knudsen, 2006), and the contradictions women find themselves traversing. Such intersectionalities have both positive and negative impacts on women managers' perceptions of career development. Hence this paper aims to contribute to the research field of women's careers in management through the use of an intersectionality approach, with special emphasis on gendered ageism, or 'sexageism' (Carpenter, 1996). In this study I examine careers from a social constructionist perspective that emphasises the social processes by which people develop their social reality and knowledge about that reality in an ongoing way in interaction with others (Berger \& Luckmann, 1966; Burr, 1995; Cohen, Duberley \& Mallon, 2004); this perspective facilitates both an interpretative and a gender-specific analysis of the data within the specific social context, which in this case means work organisations in a country with a strong ethos of gender equality.

The first section of this paper addresses how gender and age intersect in women managers' careers, and contextualises the study and the data through brief introductions to relevant aspects of age, ageism and management, and to the cultural context in Finland. Across two empirical 
sections I present an analysis of the data on gendered ageism, and on age as both a tension as well as an empowering dimension in women managers' careers. The findings, research and policy implications are discussed in the final section.

\section{Careers and the Intersectionality of Gender and Age}

Worklife and careers are undergoing significant changes in late modern societies (van der Hejden, Schalk \& van Veldhoven, 2008). According to Castells (1998), major social transitions include the revolution in information technology, economic crises of both capitalism and the state, and an increase in new cultural and social movements. These profound societal changes are notably affecting worklife; one such new challenge includes a discontinuity in careers. 'New careers' are approached through concepts such as that of the 'patch-work' career (Blossfeld, Mills \& Bernandi, 2006; Halrynjo, 2009) or the 'kaleidoscopic career' (Mainiero $\&$ Sullivan 2006) ${ }^{\mathrm{ii}}$. Hence the traditional understanding of a career as a life-long process of work-related activities with a strongly upward, mobile, uninterrupted path is under challenge (see Hall, 2002).

New conceptualisation(s) of careers include elements of current worklife, such as the complementary co-existence of one's professional and personal life. Research on careers continues to encounter pressures for a re-evaluation of its methodologies and epistemologies (Young \& Collin, 2000). Alternatives to the still prevailing positivist framework of career theory and research have emerged through various forms of constructionism. A social constructionist approach can give a stronger voice to the interviewees, their experiences and perceptions, and address how careers are socially constructed and contextualised (Cohen et al., 2004; Young \& Collin, 2004). This study draws on social constructionism, and the interpretive approach applied allows the analysis of the intersections of gender and age in the experiences of the interviewed women managers at different ages and career stages.

The prototype of the uninterrupted, hierarchically developing career path is mainly based on men managers' life situations and on possibilities for permanent employment contracts (Tharenou, Latimer \& Conroy, 1994; Goffee \& Nicholson, 1994). Women's careers in management face more hindrances and interruptions, and thus their career paths often differ from those of men (Kirchmeyer, 1998; Mainiero \& Sullivan, 2005; Burke, 2007). Childbearing, care-giving responsibilities and the day to day emotional labour involved in work and at home are experienced in gendered ways such that they have more impact on women (Hopkins \& O’Neil, 2007; McKie, Hearn, Bowlby, Hogg \& Smith, 2008).

There are many educational and personal features and social categories that influence recruitment into and career development in management (Konrad, 2007; Dessler, 2011). Inclusion or exclusion is often not formally based on, for instance, 'suitable' or 'unsuitable' age or gender because of the anti-discrimination laws in most countries. Instead, exclusion from career development often takes place through more subtle and hidden processes of discrimination (Husu, 2001; Lämsä \& Sintonen, 2001). Inclusion may, consciously or unconsciously, be actualised through complex social and cultural relationships, networks, comradeship and homosociality, where preferences for similarity overcome formal competence criteria (e.g. Hearn \& Parkin, 1995). Being of female gender can still be characterised as a major obstacle to career advancement into top leadership and management positions in many organisations (Liff \& Ward, 2001; Wahl, 2003; Hearn, Jyrkinen, Piekkari \& Oinonen, 2008), and the processes of gendering further intersect with age factors. Senior managerial positions are traditionally held by older men, and many women's careers stagnate in middle management already at an early stage. 
Intersectionality is an approach used to reconceptualise identities, deconstruct social categories and divisions, and explore multiple marginalisations (Crenshaw, 1991). Intersectionality addresses the simultaneous existence and occurrence of multiple sociocultural categories, such as gender, race/ethnicity, age and class, and how they mutually construct, 'inter-act' and transform each other (Lykke, 2005). According to Richardson and Loubier (2008: 143), 'people live multiple, layered identities derived from social relations, history, and the operation of structured power. In other words, people are members of more than one category or social group and can simultaneously experience advantages and disadvantages related to those different social groups'.

The historical background of intersectionality is in the critical analyses of the production and reproduction of inequalities, dominance and oppression, and in critiques of the traditional identity politics that looked at different identity categories in isolation, cherishing their uniqueness (Shieds, 2008; Phoenix \& Pattynama, 2006). The experiences of women of colour led to black feminists' critique on the universalism of liberal feminism and on the neglect of race and class-based exploitation (bell hooks, 1981; Crenshaw, 1991). McCall (2005, p. 1771) claims that intersectionality is the most important theoretical contribution of women's studies and other related fields so far. However, in spite of a spate of literature on intersectionality in gender studies and other critical theory, it is still a relatively rare approach in organisation and management studies (Holvino, 2010) ${ }^{\mathrm{iii}}$.

My approach can be typified as an intracategorial complexity approach which 'acknowledges the stable and even durable relationships that social categories represent at any given point in time, though it also maintains a critical stance towards categories' (McCall, 2005, p. 1774); the aim is to reveal the complexity of the lived experience of the group being researched ${ }^{\mathrm{iv}}$. Thus the main problem is not necessarily the existence of social divisions and categories per se, but the values that are attached to them, and how these values (re)create social hierarchies, power relations, inequalities and privileges. The concept of intersectionality is used in this study to better understand how gender and age interact in women managers' careers.

\section{The Contradictory Finnish Context}

Finland has an image of gender egalitarianism based on the double-earner family model and public child care provisions (Pesonen, Tienari \& Vanhala, 2009). In Finland women are highly educated (63\% of all university degrees), are very visible in social and political life, and make up half of the workforce; $82 \%$ of Finnish women work full-time. However, care-giving is still strongly gendered, and, for instance, men use only slightly over $6 \%$ of parental leave days in Finland (Haataja, 2009). Finland has the largest share of employees with a female boss (39\%) among the EU-27 (EU average 24\%) (Parent-Thirion, Fernández Macías, Hurley \& Vermeylen, 2007). A Finnish longitudinal survey on work conditions showed that women managers get better evaluations from their subordinates than do their men counterparts in all areas studied. Accordingly, both more women (25\%) and more men (31\%) were satisfied with women bosses than with men superiors (19\% and 23\%, respectively) (Lehto, 2009). On the other hand, top leadership positions in business are still largely held by men. In 2008 women held only $12 \%$ of places on all company boards listed on the Finnish Stock Exchange, and 16\% of the board seats for the 100 largest listed companies (Statistics Finland, 2009) ${ }^{\mathrm{v}}$.

The shift towards a knowledge intensive society and ongoing demographic changes in Finland increase the need for a more diverse workforce also in management. Diversity in gender and age are relevant for corporations, their competencies and competitiveness - there are pressures 
to increase the rather low number of women involved in economic decision-making. There is also a high prevalence of age discrimination reported by women: in 2000, Finland's incidence of age discrimination experienced by women aged 45 and over during a 12-month period was highest among the EU-15 countries (Ilmarinen, 2005). These trends are repeated in the corporate world where women and men managers are situated differently within organisations (middle versus top management) and across sectors (e.g. public/private, service/production sectors, HR/line management) (Vanhala, 2003).

Currently, the Finnish economy as a whole is experiencing the constraints of an economic downturn amid concerns about innovation for future economic development. The downturn is shifting the economy towards social and commercial reorganisation. Old structures, such as the clear division of 'the public' and 'the private', are being challenged and are changing. The third sector is becoming more important: many non-governmental organisations are increasingly taking on the original duties of the state, such as eldercare. Aging of the population has led to pressures to lengthen people's careers, and political debates on the measures needed have intensified at the same time as precarious work and unemployment have increased in society.

To summarise, age(ism) and gender intersect in many ways that are challenging for women in management and for employers in general. In international contexts Finland has a strong image as a country with successful gender equality policies. Official statements emphasise gender equality achievements and gender-neutrality as a basis of Finnish civil society and law, and note the involvement of women at senior levels of political decision-making, in civil society and in the public sector. Although there have been many advancements in the position of women in Finnish society, there are also many shortcomings as regards women's careers in management.

\section{The Study}

The data consisted of 15 semi-structured interviews with women holding senior management positions in a business or in a third sector organisation in Finland. The interviews, gathered in 2008-2009, each lasted between 60 and 180 minutes. The interviews ${ }^{\mathrm{vi}}$ were structured around three major areas related to age and gender: career phases; organisational policies and relationships with work colleagues; and mentors, networks and NGOs ${ }^{\text {vii }}$. The data set was gathered by approaching two professional women's organisations and asking for advice in searching for suitable interviewees, followed by a snowballing technique as an additional way to find suitable interviewees. Two of the interviewed women had recently retired from their actual jobs, but continued to work for their employers as consultants or experts. The average number of children of the interviewees was 1.8 , consistent with the fertility rate for the whole of Finland (Eurostat, 2008). Socioeconomic data for the interviewees are given in Table 1.

\section{Table 1. Socioeconomic Data on the Study Interviewees}

At the beginning of each interview a written contract on confidentiality was drawn up to assure anonymity and the possibility for interviewees to express with maximum frankness their views and feelings on such difficult and personal issues. The sensitivity of the topic - age and gender in relation to the careers and lives of the interviewees - was a challenge in the search for access to interviewees and in the actual interviews. Studying sensitive topics calls for addressing specific ethical issues in the research process and in the method(s) used (see Hearn, 1998; Jyrkinen, 2005). Thus any ethical questions become methodological questions. According to Lee and Renzetti (1993, p. 5), a sensitive topic is one that can potentially pose substantial threat to the researcher and/or the researched during the collection and holding of the data or 
dissemination of the results. The research process may become difficult because informants are not willing to give information on issues that are taboo or intimate, and/or because opening up such issues may be particularly stressful.

In this study, ethical issues around confidentiality, the data analysis and the actual interview situation were carefully considered (see British Sociological Association, 2002; Academy of Finland, 2009). The challenge was to create an atmosphere of trust in the interviews which could enable the exploration of the sensitive themes of gender and age. The fact that the interviewer was (also) a middle-aged woman probably enabled the interviewees to talk more openly. Many interviewees said that they had never spoken about the topics that came up in the interview with anyone previously. Apparently a woman interviewing women in this case enabled more open discussion, but at the same time, had the potential to bring up some bias, i.e. more focus on the negative aspects of age(ing) and gender. I tried to minimise this kind of possible bias by following the interview structure in all interviews as much as possible, hence giving attention also to positive aspects of gender and age. Reflexivity of both the interviewees, myself as the researcher, and this relationship was an important part of the research process.

All interviews were tape-recorded and transcribed ${ }^{\text {viii }}$, yielding over 400 pages of text. A research diary and notes that I kept during data collection were used in the analysis in order to reflect upon the situational matters of the interviews. The data reading was interpretative and based on thematic analysis (Langdridge, 2004). The analysis concentrated on the main research question, namely the impacts of age and gender on the careers of women managers. After reading and re-reading the transcripts carefully, I coded the data according to 16 coding categories (see Appendix 2). At the next stage of the analysis, the codings and their interrelations were developed into two more overarching themes, namely gendered ageism, and the tensions and empowerments of age.

A limitation of this research is, as with any qualitative project, its restricted scope, and therefore, it is not possible to make strong generalisations (Mason, 2002). The strength of the approach is the depth and complexity of the data, which allows the researcher to explore in detail women's experiences of their careers and gendered ageism. Another key strength is the uniqueness of the data, as most interviewees expressed that this was the first time that they talked about issues on gender, age and their intersections, facilitated by the sense of trust in the interview situation.

\section{Gendered Ageism and Careers}

In the interviews women managers talked passionately about their interest in aspects of their work and their commitment to jobs, but also about gender discrimination during their careers, which often took egregious forms and had serious impacts. Gender discrimination is illegal in Finland as in other EU countries, and the discrimination that the interviewees had encountered took place in more hidden forms (Husu 2001) and was often associated with the woman's age. Gender and age went hand in hand, and ageism in the data was strongly gendered, as one interview, Ellen, describes:

And in organisations there is definitely ageism (--) a lot, and it concerns especially women more. It does not matter what kind of old grey-haired chap [a man is], he can easily be the chairperson of the company board (--). And when we think about the top managerial position, women do not stay there when they get older. Or, it has to be a family business. (Ellen, NGO manager, 67) 
Ellen, a just-retired woman with long experience with managerial positions in many organisations, brought up age issues in relation to gender at the highest level of management and leadership and on boards dominated by men. She stated that senior age is not an obstacle - perhaps the opposite - to the recruitment of men managers and leaders into board positions in their late career stages, in contrary to the case for women. Ellen also thought that family businesses, or companies owned by woman themselves, offer the ultimate options for women in later career stages, as then the physical marks of ageing are not as relevant as in other business contexts. She thought that gendered ageism, in the form of negative attitudes and disparaging comments, pushes experienced women out off top managerial positions.

Also Sara, a business manager who had left a publicly listed company as her career stagnated, was of the opinion that age and gender are tightly interlinked:

Q: So they do not have any women on the board?

Sara: Not to my knowledge. (--) Then [in her case] it was the issues of age. They recruited only young and pretty women (laughs sarcastically) as assistants and elsewhere. And this seems to be the culture of the listed company, very different from the traditional family owned company it used to be earlier. It is also a question of age, as a woman is good only when she is young and pretty and has knowledge on [only] what they [men leaders] want her to have but there it ends. (Sara, business manager, 56)

Sara's interview brought many core issues of gendered ageism and careers to the fore. Sara felt that women managers have to be competent and knowledgeable, but not 'too much' so as to avoid becoming a threat to (some) men colleagues. Thus increasing one's personal knowledgebase, often related to more mature age and experience, can be a two-edged sword for women. Sara, too, was of the opinion that family businesses tend to be the safest career options for women, as such environments are perceived to offer more stable career context for ageing, competent women managers.

Gendered ageism was not encountered only in more mature age: many interviewed women brought up earlier phases of their careers in which they had experienced being referred to and treated like 'girls' by their male colleagues and superiors. The 'girling phenomenon' is that of calling adult women 'girls' and treating them as such in a disparaging way. It can sometimes be a benignly-used reference made by older men about women that unintentionally infantilises women (in leisure time, such as 'How are you girls doing tonight?'). In work contexts, girling is a derogatory wording which is attached to other genderageist actions (Martin, 2006). According to a young business manager, Thea, women managers have a very short appropriate age and time for a career: young women managers are treated like girls, followed in later age by attitudes that 'you don't understand this as you are so old'. Already in their 40s women are often automatically doomed to be stuck in their lives and careers, at least if they have young children. First women are too young, then they may be limited by child care responsibilities, and soon after they are too old, thus caught in a trap of gender and age. Thea explained gendered ageism in the company as follows:

I have thought to myself that the only appropriate age for women is approximately 35 40 years, so some 5 years [laughs]! Before that you are a bit silly, just a girl. Then when you have small children and are 40 plus, then you are stuck. In our company we have some young men in their 30s who said 'you don't understand anything about this as you are so old'. (Thea, business manager, 44) 
Many younger interviewees brought up that 'one should not miss one's moment' i.e. the need to make a breakthrough career-wise when young. At the same time, younger women were worried about how pregnancy and family would impact on their careers. In spite of the Finnish legislation that guarantees a year of maternity leave and two to three years of parental leave, Viola did not dare to use these rights as she thought that staying away from work would endanger her career:

I did not dare to take the risk and stay at home after childbirth [for more than 8 months], because I was afraid that it would impact my career. (--) I definitely think that men who are the same age as me have proceeded to these positions at much younger age! (Viola, business manager, 44)

Like Viola, many interviewees described incidences of losing career advancement possibilities, at least for a while, in comparison to younger male candidates. Men were described as climbing the hierarchical career ladder faster than many women. Earlier studies have indicated that homosociality enhances men's career progress in many organisations (see Holgesson, 2003). Young men may proceed faster than many women as they are not expected to take parental leave (Kiianmaa, 2012). Gendered care responsibilities (children, elderly parents, friends) cause hurdles in women's careers at many stages and ages (Jyrkinen \& McKie, 2012).

According to Itzin and Phillipson (1995), women are often understood and defined as ageing at an earlier chronological age than are men, which poses challenges for women's careers and brings pressure to stay 'youngish looking'. 'Looks' was an issue that many women interviewees pondered, sometimes involuntarily, throughout their worklives. This was present in all age groups of women managers.

I am scared that age becomes an obstacle, even though I feel freer and stronger nowadays. On the other hand, I am scared about [physical] ageing, and terrified to look at myself in the mirror in the mornings. (--) Everyone wants to be young and successful! (Viola, business manager, 44)

In spite of her successful career development and feelings of freedom and strength through maturing, Viola worried about age and ageism, and she talked about the embedded gendered aspects related to looks. She feared looking at the mirror in the mornings without make-up, as the pressures to be young relate to success in careers - in particular as far as women are concerned. She stated that physical age does not necessarily correlate with mental age, and people can stay 'youngish' across all age groups. But according to Viola, it is typical that an 'old male grey eminence is looked at in a different way than an old grey woman'. Also Sara, a very experienced business manager, described the pressures to be slim, well-groomed and preferably youngish or ageless in order to meet the embedded and gendered qualifications for women in business communities:

The outside world expects you [women managers] to be slim and well-groomed and all these kind of things in order to be qualified in this [business] world. (Sara, business manager, 56)

As the quotes above indicate, the issues of age, ageing and 'looks' posed pressures for women managers' worklives both when young and in later stages of their careers. The intersectionality of gender and age thus depends on their bodily dimension and expressions (see Martin, 2003). 
One interviewee who had attended many international and national working groups and conferences on issues related to age - all of which disregarded any gender analysis - explained that she was rather amazed at how age was defined: 'already after 45 years one can be defined as 'ageing', Lisa explained.

I was rather shocked that already 45 plus is defined as 'ageing'. (--) That over 45 years of age means that we are treated as a problem. And we 'baby boomers' are looked at like toxic waste, saying that 'Why on earth do you not retire already?' And on the other hand (--) if I do not continue to work until I am 68, my pension is really small. Do I have to stay [in worklife] for over eight more years hearing that I am too old? (Lisa, NGO manager, 59)

This quote by Lisa brings up the contradiction between the wish of governments that people stay in work longer and, on the other hand, the claim that older workers 'block' the way for younger generations to proceed into professional or managerial positions. Pensions ${ }^{\mathrm{ix}}$ in Finland are calculated based on the years of work and salary level. As women's salaries are approximately $20 \%$ lower than men's, their pensions are also lower in general. Women's pensions are lower than men's also because many women stay home at least some time after childbirth. These facts might 'encourage' women to stay longer in working life. In addition, as somewhat older women usually do not have child care responsibilities, they have the possibility to focus on work and their careers.

\section{Age as Tension and Empowerment}

The second theme discussed here deals with tensions at the workplace that women managers encounter, and age as an empowering aspect in one's career. The data reveals that many women experience 'always being the wrong age', as has been indicated also in earlier studies (e.g. Duncan \& Loretto, 2004). When I asked about the 'best age' in career and life, the interviewees in general expressed satisfaction with their current age and career, but at the same time many brought up that age is an 'issue' for women already in early mid-age. According to Susan, women managers' age is under the microscope at workplaces, as exemplified by genderageist and derogatory comments about menopause in cases of disagreement with co-workers.

It seems that the 'best age' for women managers is between 38 and 40 years! Over 40 seems to be a problem for women (--) and questions about menopause are posed. For men it seems to be easier. (Susan, business manager, 33)

Sara echoed how women already in their 40s are easily interpreted as too old for serious career progress:

Q: And when one gets to her 40 s...

I: Then she is already too old. (--) Whatever age you [as a woman] are, there is always something negative about it. (Sara, Business owner, 56)

(Female) gender and age intersect and tend to be of interest to others in ways that overflow from the arena of work into women manager's personal lives. Sara goes on to say that 'if you are systematically a career woman, then there is always someone [man or woman] who thinks that ok, she is not perfect because she does not have a family and she has not succeeded in that. It is often that something [negative] will be dug up, that 'what is wrong with her because she has not done this or that?" Sara's comment highlights one issue of gendered tensions at work: it is not only (some) men who are critical about women's age, as the majority of women in this 
study recounted incidences of gendered attitudes also expressed by women co-workers. Tensions between women at work may relate to the problem of tokenness, i.e. the low number of women in managerial positions who are often without the support of others.

Tensions can result in negative commenting and even 'back-stabbing' behind the scene, as indicated in media debates and discussed in some earlier research (Kanter, 1977; Wajcman, 1998; see Mavin, 2008). Duncan and Loretto (2004, p. 109) write that women 'were likely to be harsher on their own sex than on men, providing an indication that they had internalised these negative gender-related assumptions'. According to this data, age is a weapon even in woman to woman relations. Among the study interviewees, Elisabeth, for example, had experienced envy between women related to her 'youthfulness' and was the explanation for many conflicts.

But maybe I do dress up in a rather youngish fashion, and I wear these kinds of shortish skirts. Just recently one woman in the same age group as I am commented that 'you look so good, you are so good-looking, and how can that be so, even though that we are the same age'. (--) I wear these kinds of prettier things when at work, things that are youngish. (Elisabeth, NGO manager, 59)

Tensions between women managers and their subordinates and colleagues can actualise because of differences between women co-workers in terms of career and home orientations and life phases (see Maddock \& Parkin, 1994). In particular child care responsibilities can enhance conflicts between those who have young family members and those who are single or childless. This was discussed by younger mangers as follows:

I remember that I have [when younger] said [to women subordinates] 'doesn't your husband ever take care of [sick] children?' That was a terrible comment from a person who at that time did not yet have children! I am sure that they [subordinates] have hidden these words deep [in their hearts]. But in that company it was the case that women did take care of sick children. (Viola, business manager, 44)

But a young manager does have sometimes difficulties to understand older workers, it is really so, now I understand that. Then [when very young] I did not realise this but thought that of course I pay attention to people's different situations in life. When I organised summer holidays I told one subordinate that 'you cannot have your holiday in July', and I was wondering why she keeps on asking for that. But [the reason was that] in July their nursery was closed, so therefore it was a very important issue for her. (Beatrice, business manager, 38)

Both Viola and Beatrice had realised that some of their past behaviour had caused problems and tensions at work. Viola regretted her comment about only women taking care of sick children - a comment which women subordinates had assumingly found offensive. Gendered care responsibilities (McKie et al., 2008; McKie, Biese \& Jyrkinen, 2013) cause tensions at work related to, for instance, work load issues and holiday arrangements. Beatrice had not realised that the reason one of her subordinates requested her summer holiday in July related to the fact that her child's nursery was then closed. As July is the most popular holiday season for Finns, tensions about holiday leave arise between those workers who have children and those who are childless. 
Many interviewees, like the women managers quoted above, were critically self-reflective about their actions (see Mezirow, 1991), and emphasised the importance of a supportive and consultative leadership approach. Women managers in their 50s and 60s highlighted that young women must progress, and were concerned that new generations of women do not necessarily find enough support for their careers.

We [women in management] should at the same time educate and support women to get into positions on corporate boards, but at the same time educate women to move into top managerial positions in business organisations. (Samantha, business owner, 56)

Young women contacted us a lot [in the phase of finalising their Master's theses], and when they graduated then I tried to recommend them to different places and radically used my channels [to find them positions] (--). It is of course extremely important, it is really every woman's [manager's] obligation to do so (--). At the moment I feel sometimes that there are these young women with, for example, two degrees and they can sometimes speak even seven languages and so forth, and then they cannot find a position. So this is heartbreaking. (Ellen, NGO manager, 67)

In spite of the experiences of gendered ageism discussed in the data, mid- and late-career women mangers asserted that ageing brought positive factors to working and home life, offering greater control of time and the freedom to attend work-related social events.

And think that if you need to be active 'til 68 years of age in worklife, then how many good years you still have left [at work]! And when you use your brains it keeps you lively. And then there is the point that you can also relax with people other than your family, when there are no more someones [small children] hanging on your ankle, and you are much freer to plan your work-time and activities, and can even commit to work overtime and so on. (Lisa, NGO manager, 59)

But when the children grow older and if I am still in this company, well maybe then I might consider putting my foot in the door (--). Another option that I have thought about is that after these seven years in this company to slowly start looking at other [workplaces] before I turn 50. (Tina, business manager, 45)

Women managers gained greater self-confidence with more mature age, and as Samantha, a manager with over 20 years' experience in the private and public sectors, explained, this was crucial for credibility in business consulting:

I have felt that [mature] age is beneficial in business consulting [for a woman], because when young a woman would be seen as a 'girl' (--) and when the representatives of the organisations, the managers, are often older, age is a benefit [for a woman consultant]. (--) For me the best age has been at over 50 years of age. (Samantha, business owner, 56)

Women managers in later stages of their careers expressed a great deal of satisfaction with their working life derived from greater control of their time, more freedom and more selfconfidence. At the same time, more mature women interviewees spoke of an obligation to support other women: 'lift as you climb'. They recognised the hurdles young women encounter in managerial careers. 


\section{Discussion}

The intersection of age and gender in management and careers is a relatively unexplored issue in Finland as in many other countries. Women interviewees' experiences indicate the prevalence of gendered ageism in spite of many recent policy initiatives for longer careers and in spite of well-established work for gender equality in Finnish society. This research also reveals that in work organisations gendered ageism has many forms, and women managers try to balance their careers in-between the triple jeopardy of gender, age and 'lookism' (see Granleese \& Sayer, 2005; Jyrkinen \& McKie, 2012). In many organisations women's selfpresentations, bodies and looks are subject to gendered ageism already at rather early stages of their careers, but increasingly during their senior years.

Questions about age, ageing and gender in worklife reflect on and highlight contradictions and power relations in management and leadership. Managers are supposed to have experience and knowledge gained through years of work. Knowledge is often naturally associated with older men, who do not necessarily suffer drawbacks from getting older and becoming older looking, but rather the opposite (Duncan \& Loretto, 2004; Kinnunen, 2008). Women are often interpreted to be 'old' already rather early, sometimes when they are just over 40. Older women's knowledge is not necessarily valued in the same way as that of their men counterparts - a patriarchal value system tends to exclude 'old people' when they are women. Gendered ageism replicates and reproduces the existing gender order (Connell, 1987), where power relations between women and men still remain very much unequal. The experiences of many women managers of the 'wrong age' relate to their gender, in particular to the capacity for childbirth at early and mid-career, and to the demands for a distinguished appearance and for 'youthfulness' at later career stages.

The idea(l)s of 'beauty' are well entrenched in the collective conscience through different kinds of gendered practices and processes in organisations and by the globalised media and beauty industries. They impact in particular upon women, who often encounter pressure concerning their appearances, especially when getting older. Many women managers in this study felt obliged to 'keep up their looks' in order to be successful in their careers. On the other hand, even though more senior age often increases rather than decreases the status of men in organisations and the value of their knowledge, also men may encounter uncertainties about their ageing bodies when they exhibit weaknesses, dependency and passivity (Hearn, 1995; Sinclair 2005, 2011). Another aspect is that the influence of the beauty industries spills over to include men in societies where youthful appearances, fitness/slimness and looks are becoming a collective obsession.

Women as bosses are in general well-liked in Finland (Lehto, 2009). Some earlier research has indicated that women managers tend to exercise leadership and power in an inclusive and collaborative way (Merrill-Sands, Kickul and Ingols, 2005). Support for other women was present in this data, in particular among the more mature women managers. However, there were tensions in relation to other women, too. Thus gendering management (here) with an intersectional approach makes it possible to address the differences between women, such as those between women with new families and those without. Women managers in general have limited power positions - women less often than men reach the highest echelons of leadership. Strong gender labour-market segregation in Finland and other structural and gender-based factors impact women managers' power resources. Thus high expectations of subordinate women for support and a hand up the ladder sometimes results in disappointment. Subordinate female colleagues may critique individual women managers, not recognising the impact of 
gendered structures in organisations and how deeply rooted these are, and how difficult they are to change.

In spite of experiences of gendered ageism and tensions in worklife, most interviewees were committed to and enthusiastic about their work. Many had rather kaleidoscopic careers (see Mainiero \& Sullivan, 2005), and they actively and continuously educated themselves and searched for new challenges at different age and career stages. More mature interviewees stated that becoming older and gaining more experience and self-confidence gives them more freedom and space. Hence, in spite of the serious problems gendered ageism caused for women managers, age and ageing could also be positive aspects in their careers. More mature age brought more satisfaction and power over their own lives. Thus the empowering aspects of ageing and the increase in the presence of women in the highest echelons of management may expand other, younger women's possibilities in organisations through increased support.

Research on other aspects of intersectionality such as ethnicity, nationality and sexual orientation would further illuminate the complex interplay of power in careers in management. Although gendered ageism is a problem particularly for women because of-sexism still embedded in current societies, future research should explore the impact of ageism on men. Research-informed knowledge on these aspects of organisational processes and practices are needed in order to construct effective inclusive and non-discriminatory policies. The ageing of the population, competition for competent workforces, and the search for new innovations in a knowledge-intensive economy are hurdles in the contemporary world. Gendered age and ageism are challenges which organisations and political decision-makers should recognise and seek to address.

\section{References}

Academy of Finland (2009). Academy of Finland Guidelines on Research Ethics http://www.aka.fi/Tiedostot/Tiedostot/Julkaisut/Suomen\%20Akatemian\%20eettiset\%20ohjee t\%202003.pdf (accessed 22.1.2012).

Acker, J. (1991). Hierarchies, jobs, bodies: a theory of gendered organisations. In Lorber, J.L. \& Farrell, S.A. (Eds.), The social construction of gender (pp. 162-179). Newbury Park, CA: Sage.

bell hooks (1981). Ain't I a woman? Black women and feminism. Boston: South End Press.

Berger, P.L. \& Luckmann, T, (1966). The social construction of reality: a treatise in the sociology of knowledge. Garden City, New York: Anchor Books.

Blossfeld, H.-P., Mills, M. \& Bernandi, F. (2006). Globalisation, uncertainty and men's careers. An international comparison. Cheltenham: Edward Elgar.

British Sociological Association (2002). Statement of ethical practice for the British Sociological Association, http://www.britsoc.co.uk/equality/Statement+Ethical+Practice (accessed 22.1.2012).

Burke, R.J. (2007). Career development of managerial women: attracting and managing talent. In D. Bilimoria \& S.K. Piderit (Eds.), Handbook on women in business and management (pp. 109-131). Cheltenham: Edward Elgar Publishing Limited. 
Burr, V. (1995). An introduction to social constructionism. London: Routledge.

Carpenter, M.W. (1996). Female grotesque in academia: ageism, antifeminism, and feminists on the faculty. In V. Clark, S. N. Garner, M. Higonnet \& K.H. Katrak (Eds.), Antifeminism in the academy (pp. 141-165). New York/London: Routledge.

Castells, M. (1998). The information age: economy, society and culture. Vol. III: End of millenium. Malden, MA: Blackwell.

Cohen, L., Duberley, J. \& Mallon, M. (2004). Social constructionism in the study of career: Accessing the parts that other approaches cannot reach. Journal of Vocational Behavior, 64, 407-422.

Connell, R.W. (1987). Gender and power: society, the person and sexual politics. Stanford, California: Stanford University Press.

Crenshaw, K.W. (1991). Mapping the margins: intersectionality, identity politics, and violence against women of colour. Stanford Law Review, 43(6), 1241-1299.

Dessler, G. (2011). Human resource management. Global Edition. Boston: Pearson.

Duncan, C. \& Loretto, W. (2004). Never the right age? Gender and age-based discrimination in employment. Gender, Work and Organization, 11(1), 95-115.

Eurostat (2008). Population and social conditions, http://epp.eurostat.ec.europa.eu/cache/ITY_OFFPUB/KS-SF-08-081/EN/KS-SF-08-081-

EN.PDF (accessed 12.10.2009).

Goffee, R. \& Nicholson, N. (1994). Career development in male and female managers convergence or collapse? In M.J. Davidson \& R.J. Burke (Eds.), Women in management. Current research issues (pp. 80-91). London: Paul Chapman Publishing.

Granleese, J. \& Sayer, G. (2005). Gendered ageism and "lookism": a triple jeopardy for female academics. Women in Management Review, 21(6), 500-517.

Haataja, A. (2009). Fathers' use of paternity and parental leave in the Nordic countries. The Social Insurance Institution of Finland: Helsinki.

Hall, D.T. (2002). Careers in and out of organisations. Thousand Oaks: Sage.

Halrynjo, S. (2009). Men's work-life conflict: career, care and self-realization: patterns and privileges and dilemmas. Gender, Work and Organization, 16, 1, 98-125.

Hearn, J. (1995). Imagining the aging of men. In M. Featherstone and A. Wernick (Eds.), Images of aging: Cultural representations of later life (pp. 97-115). London: Routlege.

Hearn, J. (1998). The violences of men. London: Sage. 
Hearn, J., Jyrkinen, M., Piekkari, R. \& Oinonen, E. (2008). Women home and away: transnational work and gender relations. Journal of Business Ethics, special issue Women, globalisation and global management, 83(1), 41-54.

Hearn, J. \& Parkin, W. (1995). 'Sex' at 'work': the power and paradox of organisation sexuality. Revised edition. New York: St.Martin's Press.

van der Hejden, Schalk, R. \& van Veldhoven, J.P.M. (2008). Ageing and careers: European research on long-tem career development and early retirement. Career Development International, 13(2), 85-94.

Holgersson, C. (2003). Rekrytering av företagsledare. En studie i homosocialitet [The recruitment of managing directors - a study on homosociality]. Stockholm: Ekonomiska Forskningsinstitutet vid Handelshögskolan i Stockholm.

Holvino, E. (2010). Intersections: the simultaneity of race, gender and class in organisation studies. Gender, Work and Organization, 17(3), 248-277.

Hopkins, M.M. \& O’Neil, D.A. (2007). Women and success: dilemmas and opportunities. In D. Bilimoria \& S.K. Piderit (Eds.), Handbook on Women in Business and Management (pp. 132-153). Cheltenham: Edward Elgar Publishing Limited.

Husu, L. (2001). Sexism, support and survival in academia. Academic women and hidden discrimination in Finland. Helsinki: Department of Social Psychology, University of Helsinki.

Ilmarinen, J. (2005). Towards a longer worklife! Ageing and the quality of worklife in the European Union. Helsinki: Finnish Institute of Occupational Health \& Ministry of Social Affairs and Health.

Itzin, C. \& Phillipson, C. (1995). Gendered ageism: a double jeopardy for women in organisations. In C. Itzin \& C. Phillipson (Eds.), Gender, culture and organisational change. Putting theory into practice (pp. 84-94). London: Routledge.

Jyrkinen, M. (2005). The organisation of policy meets the commercialisation of sex. Global linkages, policies, technologies. Ekonomi och samhälle No 146. Helsinki: Hanken, Swedish School of Economics and Business Administration (available at: http://hdl.handle.net/10227/118).

Jyrkinen, M. \& McKie, L. (2012). Gender, age and ageism: experiences of women managers in two EU countries. Work, Employment and Society, 26(1), 61-77.

Kanter, R.M. (1977). Men and women of the corporation. New York: Basic Books.

Kiianmaa, N. (2012). Tasa-arvobarometri [Gender quality baraometer]. Sosiaali- ja terveysministeriön julkaisuja 13. Helsinki: Sosiaali- ja terveysministeriö.

Kinnunen, T. (2008). Lihaan leikattu kauneus [Beauty cut in flesh]. Helsinki: Gaudeamus.

Kirchmeyer, C. (1998). Determinants of managerial career success: evidence and explanation of male/female differences. Journal of Management, 24, 673-692. 
Knudsen, S.V. (2006). Intersectionality - a theoretical inspiration in the analysis of minority cultures and identities in textbooks. In E. Bruillard, M. Horsley, S.V. Knudsen \& B. Aamotsbakken (Eds.), Caught in the web or lost in the textbook (pp. 61-76). Paris: IUFM de Caen.

Konrad, A., Prasad. P. \& Pringle, J. (Eds.) (2005). Handbook of workplace diversity. Sage: London

Landridge, D. (2004). Introduction to research methods and data analysis in psychology. Essex: Pearson Education Limited.

Lee, Raymond M. \& Renzetti, Claire M. (1993). The problems of researching sensitive topics. An overview and introduction. In C.M. Renzetti \& R.M. Lee (Eds.), Researching sensitive topics (pp. 3-13). Newbury Park: Sage.

Lehto, A.-M. (2009). Naiset valtaavat esimiespaikkoja [Women gain a foothold of managerial posts]. Hyvinvointikatsaus, 3, 14-19.

Liff, S. \& Ward, K. (2001). Distorted views through the glass ceiling: The construction of women's understandings of promotion and senior management position. Gender, Work and Organization, 8(1), 19-36.

Linnainmaa, L. (2012). The glass ceiling is cracking. Self-regulation beats quotas. Report by the Finland Chamber of Commerce. Helsinki: Finland Chamber of Commerce (available at: .http://naisjohtajat.fi/files/2012/05/THE-GLASS-CEILING-IS-CRACKING_Self-regulationBeats-Quotas_finncham.pdf).

Ludeman, K. \& Erlandson, E. (2006). The alpha male syndrome. Boston, Massachusetts: Harvard Business School Press.

Lykke, N. (2005). Nya perspektiv på intersektionalitet. Problem och möjligheter [New perspectives of intersectionality. Problems and possibilitites]. Kvinnovetenskaplig tidskrift, 23, 7-17.

Lämsä, A.-M. \& Sintonen, T. (2001). A discursive approach to understanding women leaders in working life. Journal of Business Ethics, 34, 255-267.

Maddock, S. \& Parkin, D. (1994). Gender cultures: how they affect men and women at work. In M.J. Davidson \& R.J. Burke (Eds.), Women in management. Current research issues (pp. 29-40). London: Paul Chapman Publishing.

Mainiero, L.A. \& Sullivan, S.E. (2005). Kaleidoscope careers: an alternative explanation for the opt-out revolution. Academy of Management Executive, 19(1), 106-123.

Mainiero, L. \& Sullivan, S. (2006) The opt-out revolt: why people are leaving companies to create kaleidoscope careers. Mountain View, CA: Davies-Black Publishing.

Martin, Y.P. (2003). "Said and done" versus "saying and doing": gendering practices, practicing gender at work. Gender and Society, 17(3), 342-366. 
Martin, Y.P. (2006). Practicing gender at work: further thoughts on reflectivity. Gender, Work and Organization, 13(3), 254-276.

Mason, Jennifer (2002) Qualitative researching. $2^{\text {nd }}$ edition. London: Sage.

Mavin, S. (2008). Queen bees, wannabees and afraid to bees: no more 'best enemies' for women in management? British Journal of Management, 19, 75-84.

McCall, L. (2005). The complexity of intersectionality. Signs: Journal of Women in Culture and Society, 30(3), 1771-1800.

McKie, L., Biese, I. \& Jyrkinen, M. (2013).’The best time is now!': The temporal and spatial dynamics of women opting in to self-employment. Special issue Frayed careers: rhythms of working lives, Gender Work and Organization, 20(2), 184-196.

McKie, L., Hearn, J., Bowlby, S., Hogg, G. \& Smith, A. (2008). Organisation carescapes: researching organisations, work and care. Working papers 538, Hanken School of Economics (available at: http://urn.fi/URN:ISBN:978-952-232-014-8).

Merrill-Sands, D., Kickul, J. \& Ingols, C. (2005). Women pursuing leadership and power: the myth of the "opt out revolution". CGO Insight, No.20. Boston, MA: Center for Gender in Organizations, Simmons School of Management.

Mezirow, J. (1991). Transformative dimensions of adult learning. Jossey-Bass: San Francisco.

Moore, S. (2009). 'No matter what I did I would still end up in the same position': age as a factor defining older women's experience of labour market participation. Work, Employment and Society, 23(4), 655-671.

Parent-Thirion, A., Fernández Macías, E., Hurley, J. \& Vermeylen, G. (2007), Fourth European Working Conditions Survey. Dublin: European Foundation for the Improvement of Living and Working Conditions, http://www.eurofound.europa.eu/pubdocs/2006/98/en/2/ef0698en.pdf (accessed 5.1.2012).

Pesonen, S., Tienari, J. \& Vanhala, S. (2009). The boardroom gender paradox. Gender in Management: An International Journal, 24(5), 327-345.

Phoenix, A. \& Pattynama, P. (2006). Intersectionality. European Journal of Women's Studies. 13(3), 187-192.

Prasad, P. \& Mills, A. J. (1997). From showcase to shadow. Understanding the dilemmas of managing workplace diversity. In P. Prasad, A. J. Mills, M. Elmes \& A. Prasad (Eds.), Managing the organisational melting pot. Dilemmas of workplace diversity (pp. 3-27). Thousand Oaks: Sage.

Perry, E.L. \& Parlamis. J.D. (2006). Age and ageism in organisations. A review and considerations of national culture. In A.M. Kondad, P. Prasad \& J.K. Pringle (Eds.), Handbook of workplace diversity (pp. 346-370). London: Sage. 
Richardson A. \& Loubier, C. (2008). Intersectionality and leadership. International Journal of Leadership Studies, 3(2), 142-161.

Shields, S.A. (2008). Gender: an intersectionality perspective. Sex Roles, 59, 301-311.

Sinclair, A. (2005). Body possibilities in leadership. Leadership, 1(4):387-406.

Sinclair, A. (2011). Leading with body. In E. Jeanes, D. Knight \& P.Y. Martin (Eds.), Handbook of gender, work and organization (pp. 117-130). Wiltshire: John Wiley \& Sons Ltd.

Statistics Finland (2009) Naiset eivät etene korkeimpiin tehtäviin [Women do not proceed into highest positions]. Tiedote 25.8.2009, http://www.stat.fi/ajk/tiedotteet/2009/tiedote_010_2009-08-25.html (accessed 2.2.2011).

Tharenou, P., Latimer, S. \& Conroy D. (1994). How do you make it to the top? An examination of influences on women's and men's managerial advancement. Academy of Management Journal, 37, 899-931.

Traxler, A. J. (1980). Let's get gerontologized: developing a sensitivity to aging. The multipurpose senior center concept: a training manual for practitioners working with the aging. Springfield, IL: Illinois Department of Aging.

Vinnicombe, S. \& Singh, V. (2002). Sex role stereotyping and requisites of successful top managers. Women in Management Review, 17 (3/4), 120-130.

Vanhala, S. (2003). Johtajuus yksityisissä yrityksissä: Naiset etenevät hitaasti uraputkessa [Leadership in private companies. Women's careers progress slowly]. Hyvinvointikatsaus 4: 31-37.

Virtanen, A. \& Virtanen, K. (2012). Naiset suomalaisten listayhtiöiden hallituksissa [Women on corporate boards of Finnish listed companies]. Yritysetiikka, 1, 6-16.

Wahl, A. (2003). Sammanfattande kommentarer [Conclusions]. Mansdominans i förändring. Om ledningsgrupper och styrelser (pp. 245-267) [Male dominance in flux. On executive groups and boards]. Betänkande av Utredning om kvinnor på ledande poster i näringslivet. SOU 2003:16. Stockholm: Fritzes.

Wajcman, J. (1998). Managing like a man. Blackwell, Oxford.

Wilkinson, J.A. \& Ferraro, K.F. (2002). Thirty years of ageism research. In T.D. Nelson (Ed.), Ageism: stereotyping and prejudice against older persons (pp. 339-358). New Baskerville: Massachusetts Institute of Technology.

Young, R.A. \& Collin, A. (2000). Introduction: framing the future of career. In A. Collin \& R.A. Young (Eds.), The future of career (pp. 1-17). Cambridge university press: Cambridge.

Young, R.A. \& Collin, A. (2004). Introduction: Constructivism and social constructivism in the career field. Journal of Vocational Behavior, 64, 373-388. 


\footnotetext{
${ }^{i}$ According to Traxler (1980), four factors contribute to the negative image of ageing in western societies: the fear of death, which is associated with old age; emphasis on the youth culture in the media and the valuing of youth, physical beauty and sexuality; emphasis on a narrowly defined culture of productivity, where older people are interpreted as being ineffective; and poorly controlled gerontological studies which have reinforced the negative image of the older adult.

ii 'Patchwork careers' refers to situations where the person takes up more or less voluntarily different kinds work tasks. Career choices are based on the personal life situation, lifestyle and goals for self-fulfilment (Blossfeld, Mills \& Bernandi, 2006; Halrynjo, 2009). Mainiero and Sullivan (2006) developed the concept of the kaleidoscopic career model to help explain the multidimensional, cyclical nature of a woman's life and career times of work and times of no work when inappropriate to one's family and life situation.

iii 'Diversity management' has gained increased interest in management theory and practice, referring to systematic and planned commitment on the part of the organisations to recruit, retain and promote employees from diverse demographic and ethnic backgrounds. This approach differs from intersectionality theory's subject position, and in spite of its merits, it has also gained wide criticism (e.g. Prasad \& Mills, 1997).

iv Intersectionality theory has been criticised for essentialism and for reconstructing social categories, especially by writers with postmodern perspectives (see Moore, 2009). I empathise with Crenshaw's (1991) response to this kind of critique, and echo that to state that social divisions or categories such as gender or age are socially constructed does not mean that they are nonrelevant.

$\checkmark$ The number of women on boards of directors has increased during recent years in Finland. According to the report by the Finland Chamber of Commerce (FinnCham), in 2011 women held 18\% and in 2012 they held 22\% of the board positions in listed companies (Linnainmaa, 2012). However, according to Virtanen and Virtanen (2012), the increase in women on boards in Finland has been slow - the number of listed companies in Finland is quite small (e.g. 124 in 2011), and the per cent increase may seem more impressive than the actual change.

vi The interview outline is attached as Appendix 1.

vii I chose to include the third sector in this research to help address the gap left by earlier studies, most of which have focused on companies and/or public sector organisations; NGOs play an increasingly important role in current civil societies. The NGOs where the women manager interviewees in this study worked are large organisations with high status in Finnish society.

viii An agreement of confidentiality was made with the transcriber.

${ }^{\text {ix }}$ All in Finland get a basic-level pension, which is small (at maximum 590 Euros per month).
} 